\title{
Effect of different dye solutions on the evaluation of the sealing ability of mineral trioxide aggregate
}

\section{Efeito de diferentes soluções corantes na avaliação da capacidade seladora do agregado de trióxido mineral}

\author{
Mário Tanomaru Filho* \\ Frederick Alves Figueiredo** \\ Juliane Maria Guerreiro Tanomaru***
}

\begin{abstract}
Alkaline materials have shown incompatibility with methylene blue dye in leakage experiments. The goal of the present study was to analyze the effect of different dyes on the evaluation of the apical sealing ability of Mineral Trioxide Aggregate root-end fillings. Fifty-six extracted human canines were submitted to root canal instrumentation and obturation. After apical resection, retrograde cavities were prepared and teeth were randomly divided into four experimental $(n=13)$ and two control groups $(n=2)$. The following root-end filling materials were used: groups 1 and 2 - Pro Root MTA (Dentsply), groups 3 and 4 - zinc oxide-eugenol cement (ZOE). Teeth in groups 1 and 3 were immersed in $2 \%$ methylene blue solution, while teeth in groups 2 and 4 were immersed in $0.2 \%$ rhodamine $\mathrm{B}$ in a reduced pressure environment for 48 hours. Teeth were then longitudinally sectioned and leakage was evaluated. Results were submitted to statistical analysis (ANOVA and Tukey's test). Group 1 presented the least leakage $(\mathrm{p}<0.05)$. It was concluded that the evaluation of the sealing ability of MTA is influenced by the dye used, since this material presented better sealing ability when evaluated with Methylene Blue, but was similar to ZOE when evaluated with rhodamine B.
\end{abstract}

DESCRIPTORS: Dental leakage; Retrograde obturation; Mineral trioxide aggregate.

RESUMO: Tem sido demonstrada a incompatibilidade de materiais alcalinos com a solução corante de azul de metileno utilizada em testes de infiltração marginal. O objetivo do presente estudo foi analisar a influência de diferentes soluções corantes na avaliação do selamento apical proporcionado pelo agregado de trióxido mineral. Cinqüenta e seis caninos humanos extraídos tiveram seus canais radiculares instrumentados e obturados. Após a secção da porção apical, cavidades retrógradas foram preparadas e os dentes divididos aleatoriamente em quatro grupos experimentais $(n=13)$ e dois controles $(n=2)$. Foram utilizados os seguintes materiais retrobturadores: grupos 1 e 2 - Pro Root MTA (Dentsply); grupos 3 e 4 - cimento de óxido de zinco e eugenol (OZE). Em seguida, os dentes dos grupos 1 e 3 foram imersos em solução de Azul de Metileno a 2\% e dos grupos 2 e 4 em solução de Rodamina B a $0,2 \%$ por 48 horas em ambiente com vácuo. Decorrido este período, os dentes foram seccionados longitudinalmente, e a infiltração marginal foi analisada. Os dados obtidos foram submetidos à análise estatística (Análise de variância e teste de Tukey). Os resultados demonstraram que o Grupo 1 apresentou menor infiltração apical que os demais $(\mathrm{p}<0,05)$. Conclui-se que a avaliação da capacidade seladora do MTA é influenciada pela solução corante, uma vez que o mesmo apresentou melhores resultados com o Azul de Metileno e infiltração marginal semelhante à do OZE quando avaliado em solução de Rodamina B.

DESCRITORES: Infiltração dentária; Obturação retrógrada; Agregado de trióxido mineral.

\section{INTRODUCTION}

The purpose of periapical surgery is to treat lesions that are not treatable by conventional endodontic therapy. Retrograde filling is a modality of periapical surgery ${ }^{6,7,13}$ that consists in the preparation and subsequent filling of an apical cavity using a root-end filling material. This material should present adequate physical/chemical properties, as well as biocompatibility, and simultaneously promote a good marginal seal.

Mineral Trioxide Aggregate (MTA), composed of tricalcium silicate, tricalcium aluminate, and other mineral oxides, is one among several rootend filling materials. MTA has shown satisfactory sealing ability as a root-end filling material ${ }^{16,18}$ and

\footnotetext{
*Associate Professor, Discipline of Endodontics; ${ }^{* *} \mathrm{DDS} ;{ }^{* * *} \mathrm{PhD}$ in Endodontics - School of Dentistry of Araraquara, São Paulo State University.
} 
Tanomaru Filho M, Figueiredo FA, Tanomaru JMG. Effect of different dye solutions on the evaluation of the sealing ability of mineral trioxide aggregate. Braz Oral Res 2005;19(2):119-22.

when used to seal lateral root perforations ${ }^{10}$. MTA has presented adequate biocompatibility both as a root-end filling material ${ }^{17}$ and in the treatment of root perforations ${ }^{8}$.

One of the methods used to evaluate the sealing ability of root canal sealers and root-end filling materials is to perform microleakage experiments employing dye solutions. Methylene blue has been routinely used to evaluate the sealing ability of dental materials ${ }^{15,18}$. However, due to its incompatibility with alkaline materials, its use has been debated. This dye may suffer decoloration by alkaline substances (such as calcium hydroxide, MTA), thus reducing its effectiveness as a tracer $^{3,4,9}$. Dye solutions indicated to evaluate the sealing ability of MTA should not be affected by alkalinity, since this material may release calcium ions and raise the $\mathrm{pH}$.

The purpose of this study was to evaluate the effect of different dye solutions on the evaluation of the apical sealing ability of Mineral Trioxide Aggregate.

\section{MATERIAL AND METHODS}

Fifty-six extracted human canines with intact and straight roots were used in this study. Immediately after extraction, teeth were placed in $1 \%$ sodium hypochlorite (School of Chemistry, UNESP, Araraquara, SP, Brazil) for 48 hours, and then stored in saline solution (Fresenius Kabi, Campinas, Brazil).

Specimens were sectioned transversally next to the cemento-enamel junction with carborundum discs (3M do Brasil, Sumaré, Brazil) under refrigeration. The working length was established with a \# 15 K-file (Dentsply Maillefer, Ballaigues, Switzerland), and the foramen diameter was standardized by inserting the same file $1.0 \mathrm{~mm}$ beyond the apical foramen. Biomechanical instrumentation was performed $1.0 \mathrm{~mm}$ short of the root length, using K-files through \#35 and saline as irrigating solution.

Subsequently, root canals were dried and obturated with a single conventional gutta percha cone (Tanariman Ind. Ltda., Manacapuru, AM, Brazil) adapted to the working length, and zinc oxide cement (S.S.White Artigos Dentários Ltda., Rio de Janeiro, RJ, Brazil).

Roots were then submitted to root-end resection using a \#699 carbide bur (KG Sorensen, São Paulo, Brazil) under slow speed. Resection was perpendicular to the long axis of the root, $3 \mathrm{~mm}$ from the apex. Retrograde cavities, $3 \mathrm{~mm}$ deep, were prepared using ultrasonic tips (S12D/90 Osada, Japan) and an ultrasonic device (Enac, Osada, Japan), under continuous irrigation with saline solution.

After cavities were prepared, roots were dried and made impermeable with two layers of epoxy adhesive (Araldite-Ciba-Geigy S.A., Taboão da Serra, SP, Brazil) and two layers of nail polish (Cosbra Cosméticos Ltda., São Paulo, Brazil), except for the sectioned surface.

Roots were randomly divided into four experimental groups with 13 specimens each, and two control groups with 2 roots each. Root-end cavities were filled with the two materials studied [Pro Root MTA (Tulsa Dentsply, Oklahoma, USA) or zinc oxide cement]. Among the 4 roots in the control groups, 2 did not receive the root-end filling (positive control) and the remaining 2 had the root-end cavities made impermeable (negative controls).

The zinc oxide and eugenol cement was manipulated in a $1 \mathrm{~g} / 0.2 \mathrm{ml}$ powder/liquid ratio, according to Bernabé ${ }^{2}$ (1994). Pro Root MTA was manipulated according to the manufacturer's instructions.

Following root-end filling, specimens in experimental groups 1 and 3 were immersed in buffered 2\% methylene blue solution (School of Chemistry, UNESP, Araraquara, SP, Brazil) in a reduced pressure environment, while specimens in experimental groups 2 and 4 were kept in buffered $0.2 \%$ rhodamine B solution (School of Chemistry, UNESP, Araraquara, SP, Brazil). All groups were maintained in the ink solution for 48 hours (Table 1).

After immersion in the dye solutions, roots were washed under running water for 24 hours. The impermeable layer was removed and roots were longitudinally sectioned from buccal to lingual with a diamond disc (KG Sorensen, São Paulo,

TABLE 1 - Distribution of the experimental groups according to the materials used.

\begin{tabular}{c|c|c}
\hline \hline Group & Root-end filler & Dye solution \\
\hline 1 & Pro Root MTA* $^{*}$ & $2 \%$ methylene blue \\
\hline 2 & Pro Root MTA* & $0.2 \%$ rhodamine B \\
\hline 3 & zinc oxide** & $2 \%$ methylene blue \\
\hline 4 & zinc oxide** & $0.2 \%$ rhodamine B \\
\hline \hline
\end{tabular}

*Tulsa Dentsply, Oklahoma, USA; **S.S.White Artigos Dentários Ltda., Rio de Janeiro, Brazil. 
Tanomaru Filho M, Figueiredo FA, Tanomaru JMG. Effect of different dye solutions on the evaluation of the sealing ability of mineral trioxide aggregate. Braz Oral Res 2005;19(2):119-22.

Brazil) under refrigeration, in order to allow exposure of the cavity and root-end filling.

Marginal leakage was observed with a Nikon ProFile projector (Model 6 C, Nippon Kogatu, Tokyo, Japan) under $20 \mathrm{X}$ magnification, from the apical wall of the retrograde cavity to the area of greater dye penetration. Results were recorded $(\mathrm{mm})$ and submitted to statistical analysis (ANOVA and Tukey's test).

\section{RESULTS}

Analysis of Variance was applied to the data obtained, and demonstrated statistically significant differences between groups. For comparison between pairs of groups, the Tukey's test was applied and showed significant difference $(p<0.05)$ between group 1 (MTA with methylene blue) and the others $(2,3$, and 4$)$, which were similar when compared with each other $(\mathrm{p}>0.05)$. The mean marginal leakage values in the experimental groups are represented in Graph 1.

Specimens in the negative control group showed no dye leakage in the retrograde cavity, while specimens in the positive control group presented extensive leakage throughout the cavity walls.

\section{DISCUSSION}

The success of root-end fillings is directly dependent on the achievement of a good apical seal, which may be accomplished by using a material with adequate properties. Among the materials

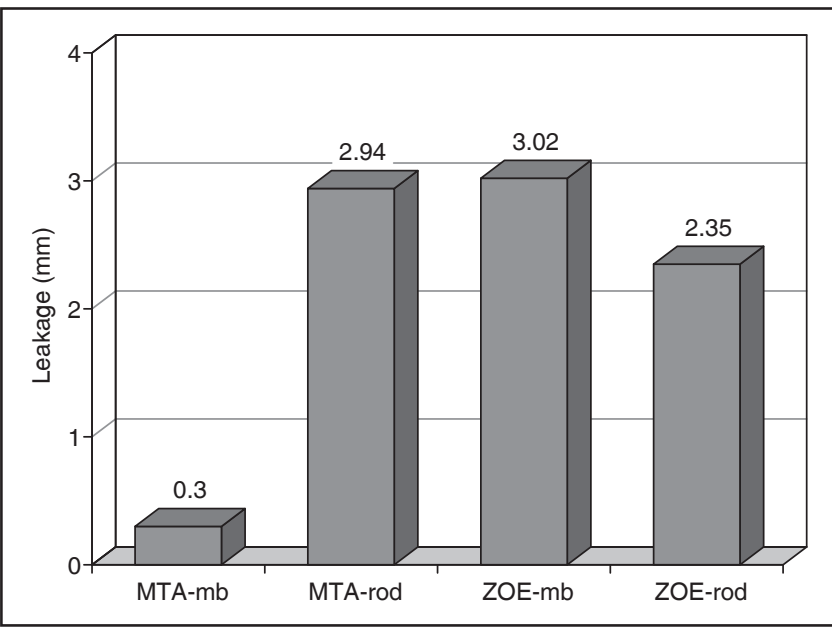

GRAPH 1 - Mean marginal apical leakage $(\mathrm{mm})$ in the MTA and zinc oxide-eugenol (ZOE) cements, with methylene blue $(\mathrm{mb})$ or rhodamine (rod) solutions. currently available, the zinc oxide-eugenol cement has been utilized ${ }^{2}$ in a higher powder/liquid ratio, in order to facilitate its condensation in the retrograde cavity.

In this study, the best sealing ability was observed in Group 1, where MTA was evaluated using methylene blue solution $(p<0.05)$. This finding may have been influenced by the dye solution used, since when MTA was evaluated using $0.2 \%$ rhodamine its leakage values were similar to those of zinc oxide-eugenol cement (evaluated with both dye solutions).

Other studies on the sealing ability of materials ${ }^{1,15,16}$ using methylene blue as a dye have also demonstrated favorable results for MTA as a root-end filling material. Greater leakage values were observed for the zinc oxide-eugenol cement with the two dye solutions, showing that the results were not influenced by the ink. The results of leakage for the zinc oxide-eugenol cement were observed in other studies, with different dye solutions ${ }^{1,10,18}$.

The use of methylene blue in marginal sealing studies has been questioned ${ }^{9,12,21}$, due to its incompatibility with alkaline substances, which may induce discoloration of the dye. The Indian ink solution has been used in studies of leakage using clearing methods ${ }^{11}$.

Calcium oxide is one of the components found in MTA. When calcium oxide is mixed with water, it results in the formation of calcium hydroxide, with a subsequent increase in $\mathrm{pH}$, as previously demonstrated by Duarte et al. ${ }^{5}$ (2003). Thus, discoloration of the surfaces marked by methylene blue may occur ${ }^{14}$. Accordingly, the rhodamine B dye solution is more appropriate for evaluating the sealing ability of MTA.

Other methods have been suggested for evaluating the sealing ability of MTA. Weldon et $a{ }^{20}$ (2002) analyzed the sealing ability of MTA and Super EBA in furcation perforations using the fluid filtration method, with good results for both materials. Valois, Costa ${ }^{19}$ (2004) evaluated MTA's sealing ability as a root-end filling material using the protein leakage method, with favorable results, especially when the material was applied in a thickness greater than $2 \mathrm{~mm}$.

\section{CONCLUSION}

Based on the methodology used and on the results obtained in this study, it may be concluded that: 
Tanomaru Filho M, Figueiredo FA, Tanomaru JMG. Effect of different dye solutions on the evaluation of the sealing ability of mineral trioxide aggregate. Braz Oral Res 2005;19(2):119-22.

1. Apical leakage was significantly lower for group 1 (MTA and methylene blue), when compared with the remaining groups $(\mathrm{p}<0.05)$.

2. Groups 2, 3, and 4 (MTA and rhodamine B, and $\mathrm{ZOE}$ with both dyes) presented similar leakage values $(\mathrm{p}>0.05)$.

\section{REFERENCES}

1. Aqrabawi J. Sealing ability of amalgam, Super-EBA cement and MTA when used as retrograde filling materials. Br Dent J 2000;188(5):266-8.

2. Bernabé PFE. Estudo histológico realizado em dentes de cães com lesão periapical após apicectomia e tratamento endodôntico via retrógrada. Influência do nível da obturação e do material obturador [Tese de Livre-Docência]. Araçatuba: Faculdade de Odontologia da Universidade Estadual Paulista Júlio de Mesquita Filho; 1994.

3. Budavari S. Methylene blue. In: The Merck Index. $11^{\text {th }}$ ed. Rahway: Merck; 1989. p. 954.

4. Cook EF, Martin EW. Farmácia prática de Remington. $10^{\text {th }}$ ed. México: Union Tipográfica Editorial Hispano Americana; 1959.

5. Duarte MAH, Demarchi AC, Yamashita JC, Kuga MC, Fraga SC. $\mathrm{pH}$ and calcium ion release of 2 root-end filling materials. Oral Surg Oral Med Oral Pathol 2003;95:345-7.

6. Friedman S, Rotstein L, Koren L, Trope M. Dye leakage in retrofilled dog teeth and its correlation with radiographic healing. J Endod 1991;17:392-5.

7. Gutmann JL, Harrison JW. Surgical endodontics. St Louis: Ishiyaku EuroAmerica; 1994.

8. Holland R, Otobonni-Filho JA, Souza V, Nery MJ, Bernabé $\mathrm{PF}$, Dezan ED. Mineral trioxide aggregate repair of lateral root perforations. J Endod 2001;27:281-4.

9. Kontakiotis EG, Wu MK, Wesselink PR. Effect of calcium hydroxide dressing on seal of permanent root filling. Endod Dent Traumatol 1997;13:281-4.

10. Lee SJ, Monsef M, Torabinejad M. Sealing ability of a mineral trioxide aggregate for repair of lateral root perforations. J Endod 1993;19:541-4.

11. Leonard JE, Gutmann JL, Guo IY. Apical and coronal seal of roots obturated with a dentin bonding agent and resin. Int Endod J 1996;29:76-83.
3. It was observed that the dye used influenced the evaluation of MTA's sealing ability; that is, marginal leakage values were lower when MTA was evaluated with methylene blue, when compared with the values obtained by $\mathrm{ZOE}$ with both dyes $(\mathrm{p}<0.05)$.

12. Moraes IG, Nunes E, Berbert A, Duarte MAH, Betti LV. Influência do hidróxido de cálcio e do EDTA na marcação da infiltração marginal de azul de metileno em obturações de canais radiculares. Rev Fac Odontol Bauru 2000;8:37-44.

13. Rud J, Andreasen JO. A study of failures after endodontic surgery by radiographic, histologic and stereomicroscopic methods. Int J Oral Surg 1972;1:311-28.

14. Silva Neto UX, Brochado VHD, Gonçalves Júnior JF. Infiltração marginal em obturações retrógradas realizadas com ProRoot-MTA, MTA-Angelus e Super-EBA [Abstract]. Pesqui Odontol Bras 2002;16(Supl):131.

15. Tanomaru Filho M, Tanomaru JMG, Ashikawa TM. Capacidade de selamento apical de materiais retrobturadores à base de Agregado de Trióxido Mineral. J Bras Endod 2003;4:20-3.

16. Torabinejad M, Higa RK, McKendry DJ, Pitt Ford TR. Dye leakage of four root end filling materials: effects of blood contamination. J Endod 1994;20:159-63.

17. Torabinejad M, Pitt Ford TR, McKendry DJ, Abedi HR, Miller DA, Kariyawasam SP. Histologic assessment of mineral trioxide aggregate as a root-end filling in monkeys. J Endod 1997;23:225-8.

18. Torabinejad M, Watson TF, Pitt Ford TR. Sealing ability of a mineral trioxide aggregate when used as a root end filling material. J Endod 1993;19:591-5.

19. Valois CR, Costa ED. Influence of the thickness of mineral trioxide aggregate on sealing ability of root-end fillings in vitro. Oral Surg Oral Med Oral Pathol 2004;97:108-11.

20. Weldon JK, Pashley DH, Loushine RJ, Séller RN, Kimbrough WR. Sealing ability of mineral trioxide aggregate and super-EBA when used as furcation repair materials: a longitudinal study. J Endod 2002;28:467-70.

21. Wu MK, Kontakiotis EG, Wesselink PR. Decoloration of $1 \%$ methylene blue solution in contact with dental filling materials. J Dent 1998;26:585-9.

Received for publication on Feb 15, 2005

Sent for alterations on May 24, 2005

Accepted for publication on Jun 22, 2005 